\title{
Tubal Epithelial Hyperplasia
}

National Cancer Institute

\section{Source}

National Cancer Institute. Tubal Epithelial Hyperplasia. NCI Thesaurus. Code C40117.

A hyperplasia of the tubular epithelial cells. 